\title{
Shade and Nitrogen Influence Gas Exchange and Growth of Cocoyam (Xanthosoma sagittifolium)
}

\author{
Hector R. Valenzuela, Bruce Schaffer, and Stephen K. O'Hair \\ Tropical Research and Education Center, Institute of Food and Agricultural Sciences, University of \\ Florida, 18905 S. W. 280 Street, Homestead, FL 33031-3314
}

Additional index words. aroids, tannia, net $\mathrm{CO}_{2}$ assimilation, light interception, photosynthesis, chlorophyll

\begin{abstract}
Net gas exchange and growth were determined for cocoyam [Xanthosoma sagittifolium (L.) Schott] growing in $30 \%, 50 \%$, and $100 \%$ sunlight and fertilized with 0 or $475 \mathrm{mg} \mathrm{N} / \mathrm{kg}$ nutrient solution. Interactions between $\mathrm{N}$ and shade were observed for lamina area per plant, top: corm ratio, corm weight, transpiration (E), stomatal conductance (g,), and lamina $\mathbf{N}$ and chlorophyll concentrations. When $\mathbf{N}$ treatments were pooled, shade-grown plants $(30 \%$ and $50 \%$ sunlight) had greater lamina areas, lamina and petiole biomass, top : corm (fresh weight) ratios, and corm fresh weights than plants grown in full sunlight. All of these criteria also had higher values for plants that received the $\mathrm{N}$ fertilizer solution $(+N)$ than for plants that received the $\mathrm{N}$-free solution $(-\mathrm{N})$, when shade treatments were pooled. When $\mathrm{N}$ treatments were pooled, $100 \%$-sunlight plants had greater net $\mathrm{CO}_{2}$ assimilation (A) rates than shade plants. Water-use efficiency (WUE), A, g., and $\mathbf{E}$ for $100 \%$-sunlight-grown plants were higher for $+\mathrm{N}$ than for $-\mathrm{N}$ plants. For shade plants, however, $A$ and $E$ were similar between $\mathbf{N}$ treatments. When $\mathbf{N}$ treatments were pooled, shade plants had a greater lamina chlorophyll concentration on a dry-weight basis than $100 \%$-sunlight plants, whereas content on an area basis was similar among shade treatments. Among shade treatments, chlorophyll contents on an area and dry-weight basis were higher for $+\mathrm{N}$ than for $-\mathrm{N}$ plants. Plants grown in $100 \%$ sunlight had higher lamina $\mathbf{N}$ concentrations (area and dry-weight bases) than shade plants. The interactions between $\mathrm{N}$ and shade showed that cocoyam response to $\mathbf{N}$ depends on incident photosynthetic photon fluxes during growth.
\end{abstract}

Lamina $\mathrm{N}$ concentration affects plant light utilization and absorption, since $\mathrm{N}$ is a major constituent of assimilating tissues (Lawlor et al., 1989; Morgan, 1988; Seeman et al., 1987; Sinclair and Horie, 1989) and is a component of ribulose bisphosphate carboxylase, an important regulator of photosynthetic activity (Bjorkman, 1972; Farineau et al., 1988; Lawlor et al., 1989; Suzuki et al., 1987). Lamina N concentration has been positively correlated with A for several plant species (Evans, 1989; Field and Mooney, 1986; Sinclair and Horie, 1989; Terashima and Evans, 1988), including aroids such as Colocasia esculenta (Sims and Pearcy, 1989) and Alocasia macrorrhiza (Seeman et al., 1987; Sims and Pearey, 1989). Nitrogen allocation appears to be involved in acclimation of plants to high PPF (Ferrar and Osmond, 1986; Joiner et al., 1977; Osmond and Chow, 1988).

The mechanism by which $\mathrm{N}$ is allocated within a leaf varies among plant species (Evans, 1989) and is affected by environmental factors, such as temperature, incident PPF, and soil fertility (Field and Mooney, 1986). Little is known about the interaction between N and PPF in the Araceae. Cocoyam, an important energy-rich food source in tropical areas, has been identified as shade tolerant with respect to growth (unpublished data) and photosynthetic activity (Schaffer and O'Hair, 1987). The perennial tropical herb produces edible rhizome-like cormels that arise from the base of the corm below the soil surface. Sims and Pearey (1989) reported that $\mathrm{N}$ content on a laminaarea basis increased with increasing PPF for Colocasia and $\mathrm{Al}$ ocasia, two close relatives of cocoyam. However, in their study, plants in the high-PPF treatments were given almost twice as much $\mathrm{N}$ as plants in the shade treatments, introducing lamina

Received for publication 26 Mar. 1990. Florida Agricultural Experiment Stations Journal Series no. R-00590. We thank R. Fethiere, Forage Evaluation Support Laboratory, Dept. of Agronomy, Univ. of Florida, for tissue N analysis; F. Martin, Statistics Dept., Univ. of Florida, for statistical analysis advice; and J. Dalton, Florida Cooperative Extension Service, Homestead, for growth media nutrient analysis. The cost of publishing this paper was defrayed in part by the payment of page charges. Under postal regulations, this paper therefore must be hereby marked advertisement solely to indicate this fact.
$\mathrm{N}$ concentration as a possible confounding factor. Chow et al. (1988) showed that Alocasia, which normally grows in deep shade, can adapt to growth in a high-light environment with respect to high A rates when given an "adequate" $\mathrm{N}$ supply. However, that study also lacked $\mathrm{N}$-free fertilizer controls. Since $\mathrm{N}$ deficits are common and $\mathrm{N}$-fertilizer costs are often prohibitive in tropical agroecosystems, where cocoyam is often grown as an intercrop, information is needed to evaluate cocoyam $\mathrm{N}$ use under diverse environmental conditions. Such baseline information can help improve the efficiency of $\mathrm{N}$ use by cocoyam in agroecosystems where $\mathrm{N}$ is a limiting resource. The purpose of the present study was to determine the effects of PPF and N fertilization during plant development on net gas exchange and growth of cocoyam.

\section{Materials and Methods}

Cocoyam cultivar South Dade White was grown in $100 \%$, $50 \%$, or $30 \%$ sunlight [maximum PPF, as determined on a cloudless day at 1300 HR with a LI-COR 190SA quantum sensor (LI-COR, Lincoln, Neb. ), was 2200, 1100, and 650 $\mu \mathrm{mol} \cdot \mathrm{s}^{-1} \cdot \mathrm{m}^{-2}$, respectively]. Mean integrated daily PPF for the $100 \%$ sunlight treatment was $37.4 \mathrm{~mol} \cdot \mathrm{m}^{-1} \cdot \mathrm{day}^{-1}$, as determined by a pyranometer (Model PSP; Eppley Laboratory, Newport, R.I.). Shade treatments were provided by $3 \times 3 \times 1.5$ $\mathrm{m}$ cages covered with neutral woven polyethylene fabric of two mesh sizes. Propagules, $\approx 300 \mathrm{~g}$, consisting of the top portion of main corms were potted in 1 peat : 1 sand $(\mathrm{v} / \mathrm{v})$ in 7.5 -liter containers. The corms were potted 28 Dec. 1988, and the experiment was concluded on 4 July 1989. Plants were irrigated daily. The experimental design was a split-plot randomized block with four replications and four single-plant samples per replication. Shade treatments were the main plots and $\mathrm{N}$ treatments were the sub-plots. Each block consisted of a "shade" cage (four cages or replications per treatment) containing both $\mathrm{N}$ -

Abbreviations: A, net $\mathrm{CO}_{2}$ assimilation; DAP, days after planting; E, transpiration; $\mathrm{g}_{s}$, stomatal conductance; PPF, photosynthetic photon flux; WUE, wateruse efficiency. 
fertilized plants (+ N plants) and plants fertilized with a $\mathrm{N}$-free nutrient solution ( $-\mathrm{N}$ plants). Half of the plants were fertilized twice weekly with the $\mathrm{N}$-free solution consisting of $178 \mathrm{mg}$ $\mathrm{MgCl}_{2}-6 \mathrm{H}_{2} \mathrm{O}, 265 \mathrm{mg} \mathrm{MgSO}_{4}-7 \mathrm{H}_{2} \mathrm{O}, 165 \mathrm{mg} \mathrm{K} \mathrm{HPO}_{4}, 82 \mathrm{mg}$ $\mathrm{K}_{2} \mathrm{HSO}_{4}, 20 \mathrm{mg}$ sequestrene $\mathrm{Fe}, 7.2 \mathrm{mg} \mathrm{MnCl}_{2}, 5.7 \mathrm{mg} \mathrm{H}_{3} \mathrm{BO}_{4}$, $0.2 \mathrm{mg} \mathrm{CuSO} \mathrm{Cu}_{4}-5 \mathrm{H}_{2} \mathrm{O}, 0.4 \mathrm{mg} \mathrm{ZnSO}_{4}-7 \mathrm{H}_{2} \mathrm{O}$, and $0.3 \mathrm{mg}$ $\mathrm{NaMoO}_{4}-2 \mathrm{H}_{2} \mathrm{O}$ per kilogram of nutrient solution. Nitrogen-fertilized plants received $475 \mathrm{mg} \mathrm{N} / \mathrm{kg}$ twice weekly from an ammonium nitrate solution plus the $\mathrm{N}$-free solution. A chemical analysis of the growing media before the beginning of the experiment showed a $\mathrm{pH}$ of 7.5 , an electrical conductivity of $50^{-4}$ $\mathrm{dS} \cdot \mathrm{m}^{-1}$, and $1 \mathrm{mg} \mathrm{N}, 2 \mathrm{mg} \mathrm{P}, 5 \mathrm{mg} \mathrm{Ca}$, and $90 \mathrm{mg} \mathrm{Cl}$ per kilogram of growing media.

Beginning 75 DAP, four monthly determinations were made of lamina 'length along the midrib, maximum lamina width, petiole length and number, and stem diameter at the soil surface. Lamina area was determined at each sampling date from the lamina length and width, based on an equation developed by us (unpublished data). Plants were harvested 180 DAP, and lamina, petiole, and corm fresh weights were determined. Tissue samples were then oven-dried at $80 \mathrm{C}$ for $72 \mathrm{hr}$ and tissue dry weights were determined.

Gas exchange was determined as described by Schaffer and O'Hair (1987). A, $g_{s}, E$, and WUE were determined in the field by enclosing lamina sections in a Parkinson leaf chamber connected to a portable $\mathrm{CO}_{2}$ and water vapor exchange analyzer (LCA-2; Analytical Development Co., Hoddesdon, Herts, U.K.). Outside air containing $340 \pm 10 \mu \mathrm{mol} \mathrm{CO}_{2} / \mathrm{mol}$ and dried to a constant $20 \% \mathrm{RH}$ was pumped into the chamber at a rate of 0.375 liters $\cdot \mathrm{min}^{-1}$. A preliminary analysis of light response for A showed that the saturating PPF for maximum A of cocoyam was $750 \mu \mathrm{mol} \cdot \mathrm{s}^{-1} \cdot \mathrm{m}^{-2}$ (data not shown). Therefore, all determinations were made at PPF $>800 \mu \mathrm{mol} \cdot \mathrm{s}^{-1} \cdot \mathrm{m}^{-2}$ using sunlight as the source. All determinations were made on cloudless days between 0930 and 1130 HR to minimize diurnal effects on gas exchange activity. Determinations were made on the youngest,- fully expanded leaves from six plants, one leaf per plant. Lamina N and chlorophyll concentrations were determined 140 and 180 DAP. Chlorophyll concentrations were determined as described by Marini and Marini (1983) and Schaffer and Gaye (1989). Nitrogen, including organic and inorganic forms, was determined by a modified Kjeldahl procedure (unpublished data). Data were analyzed by orthogonal contrast analysis. Slopes and intercepts of equations for $\mathrm{N}$ vs. growth and $\mathrm{N}$ vs. gas exchange were tested for homogeneity. When slopes and intercepts were homogeneous, $\mathrm{N}$ treatments were pooled to determine linear responses to shade.

\section{Results}

Interactions between $\mathrm{N}$ and shade $(P<0.05)$ were observed for lamina area per plant (Fig. 1B) and petiole length (data not shown) 165 DAP, stem number at all sampling dates (data not shown), top : corm ratio, and increased corm weight from planting to harvest (increased corm weight $=$ corm fresh weight 180 DAP - corm fresh weight at planting) (Fig. 2 B and C). There was no significant difference in lamina area per plant between $\mathrm{N}$ treatments for any shade treatment 75 DAP. However, by 75 DAP, there was a tendency for lamina area per plant to be greater for $+\mathrm{N}$ than for $-\mathrm{N}$ plants when shade treatments were pooled (Fig. 1A). Lamina area per plant was greater for $+\mathrm{N}$ than for $-\mathrm{N}$ plants from 105 DAP until the last sampling date 165 DAP (Fig. 1B), when shade treatments were pooled. Pooled lamina area per plant 105 DAP was 1408 and $1296 \mathrm{~cm}^{2}$ for $+\mathrm{N}$

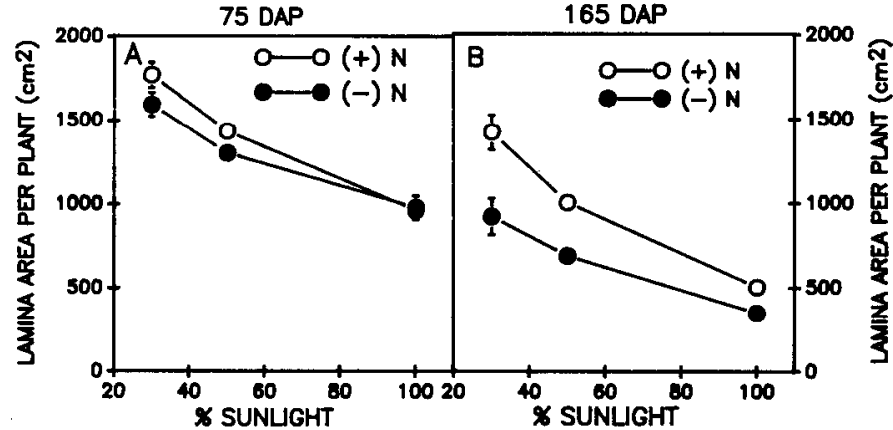

Fig. 1. Effect of percent sunlight and $\mathrm{N}$ on lamina area per plant of cocoyam (A) 75 and (B) 165 DAP. Each point represents the mean of 16 values. Vertical bars represent \pm SE. In most cases, SE bars were smaller than the symbols.

and $-\mathrm{N}$ plants, respectively. Lamina area per plant increased with increased shade at both sampling dates for both $\mathrm{N}$ treatments (Fig. 1). Stem diameter and petiole weight, length, and number increased with increased shade for plants in both $\mathrm{N}$ treatments and also were greater for $+\mathrm{N}$ than for $-\mathrm{N}$ plants when shade treatments were pooled 165 DAP (data not shown). Petiole number for $+\mathrm{N}$ plants grown in $100 \%$ sunlight decreased from 2.3 to 1.8 between 75 and 165 DAP. Petiole number, however, increased from 2.7 to 3.3 between 75 and 165 DAP for $+\mathrm{N}$ plants grown in $30 \%$ sunlight. Weight of lamina, corm fresh weights from planting to harvest, and top : corm ratios increased with increased shade (Fig. 2). In addition, these measures of growth were higher for $+\mathrm{N}$ than for $-\mathrm{N}$ plants, except for the $100 \%$-sunlight plants, which had similar corm weights and top : corm ratios for both $\mathrm{N}$ treatments (Fig. 2). The $+\mathrm{N}$ plants showed a tendency toward greater corm dry weights than $-\mathrm{N}$ plants for all shade treatments. When shade treatments were pooled, mean corm dry weight was 112 and $103 \mathrm{~g}$ for the $+\mathrm{N}$ and $-\mathrm{N}$ plants, respectively.

Interactions between applied $\mathrm{N}$ and shade $(P<0.05)$ were observed for $\mathrm{E}$ and $\mathrm{g}_{\mathrm{s}} 90$ DAP. Transpiration and $\mathrm{g}_{\mathrm{s}}$ were higher for $-\mathrm{N}$ than for $+\mathrm{N}$ plants only for $100 \%$-sunlight plants (Fig. 3 ). For the $-\mathrm{N}$ plants, $\mathrm{E}$ increased with increased PPF. The $+\mathrm{N}$ plants had a higher $\mathrm{E}$ for $50 \%$ and $100 \%$ than for $30 \%$ sunlight plants. Transpiration and $\mathrm{g}_{\mathrm{s}}$ were higher for $+\mathrm{N}$ than for $-\mathrm{N}$ plants when all shade treatments were pooled $120 \mathrm{DAP}$; the $+\mathrm{N}$ plants had a mean $\mathrm{E}$ rate of 7.1 , compared to $6.5 \mathrm{mmol}$ $\mathrm{H}_{2} \mathrm{O} / \mathrm{m}^{2}$ per sec for $-\mathrm{N}$ plants. The $+\mathrm{N}$ plants had a mean $\mathrm{g}_{\mathrm{s}}$ of 228 , compared to $186 \mathrm{mmol} \mathrm{CO}_{2} / \mathrm{m}^{2}$ per sec for $-\mathrm{N}$ plants. Transpiration and $\mathrm{g}_{\mathrm{s}} 120$ DAP were similar among shade treatments for both $\mathrm{N}$ treatments. Transpiration among $+\mathrm{N}$ plants $120 \mathrm{DAP}$ was 7.1 and $7.5 \mathrm{mmol} \mathrm{H}_{2} \mathrm{O} / \mathrm{m}^{2}$ per sec for $30 \%$ - and $100 \%$-sunlight plants, respectively. Stomatal conductance for $+\mathrm{N}$ plants 120 DAP was 279 and $214 \mathrm{mmol} \mathrm{CO}_{2} / \mathrm{m} 2$ per sec for $30 \%$ - and $100 \%$-sunlight-grown plants, respectively.

There was no difference 90 DAP in A between $\mathrm{N}$ treatments, regardless of shade level (Fig. 4A). However, A tended to be higher for $-\mathrm{N}$ than for $+\mathrm{N}$ plants 90 DAP, with mean $\mathrm{A}$ of 6.5 and $6.0 \mu \mathrm{mol} \mathrm{CO}_{2} / \mathrm{m}^{2}$ per see, respectively, when shade treatments were pooled. Net $\mathrm{CO}_{2}$ assimilation was slightly higher for $100 \%$-sunlight than for $30 \%$-sunlight-grown plants for both $\mathrm{N}$ treatments 90 DAP (Fig. 4A). By 120 DAP, A was higher for $+\mathrm{N}$ than for $-\mathrm{N}$ plants for $100 \%$-sunlight plants (Fig. 4B). Net $\mathrm{CO}_{2}$ assimilation increased with increased PPF for plants in both $\mathrm{N}$ treatments $120 \mathrm{DAP}$. When $\mathrm{N}$ treatments were pooled, no effect of shade was observed on WUE 90 DAP (data not 


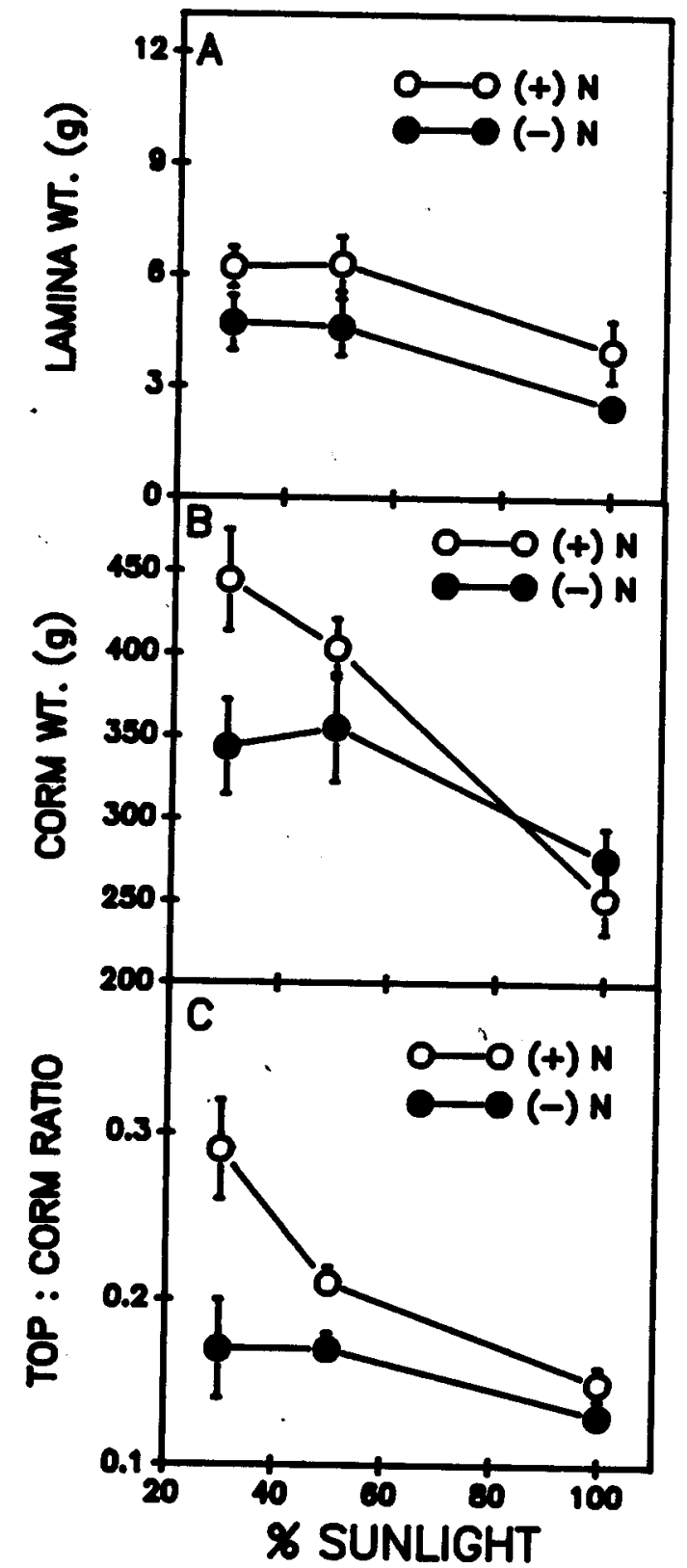

Fig. 2. Effect of percent sunlight and $\mathrm{N}$ on (A) lamina dry weight,

(B) increase in corm fresh weight from planting to harvest (fresh weight of corm 180 DAP - fresh weight of corm at planting), and (C) top :corm ratio (fresh weight) of cocoyam. Each point represents the mean of eight values 180 DAP. Vertical bars represent \pm SE. In some cases, SE bars were smaller than the symbols.

shown), but WUE increased with increasing PPF 120 DAP.

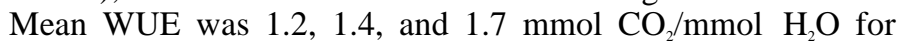
$30 \%$-, 50\%-, and 100\%-sunlight-grown plants, respectively, when $\mathrm{N}$ treatments were pooled 120 DAP. WUE was higher for $+\mathrm{N}$ than for $-\mathrm{N}$ plants when shade treatments were pooled 120 DAP, with values of 1.5 and $1.3 \mathrm{mmol} \mathrm{CO}_{2} / \mathrm{mmol} \mathrm{H}_{2} \mathrm{O}$, respectively.

Interactions between applied $\mathrm{N}$ and shade $(\mathrm{P}<0.05)$ were observed for lamina $\mathrm{N}$ concentrations (dry-weight and area bases) (Fig. 5) and for chlorophyll content per plant (Fig. 6B). Similar interactions were observed at both sampling dates (data not shown). Nitrogen concentrations were higher for $+\mathrm{N}$ than for $-\mathrm{N}$ plants only for the $100 \%$-sunlight plants and also increased with increased PPF for both N treatments 140 DAP (Fig. 5) and

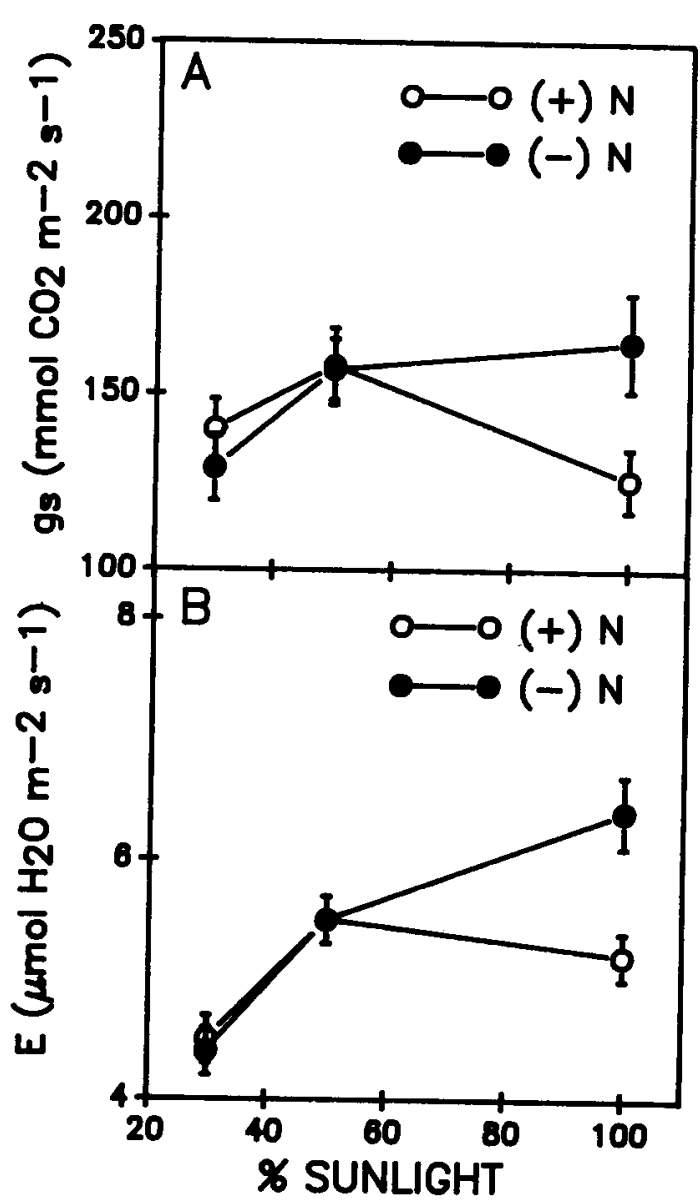

Fig. 3. Effect of percent sunlight and Non (A) stomataI conductance for $\mathrm{CO}_{2}$ and (B) transpiration of cocoyam 90 DAP. Each point represents the mean of six determinations. Vertical bars represent \pm SE.

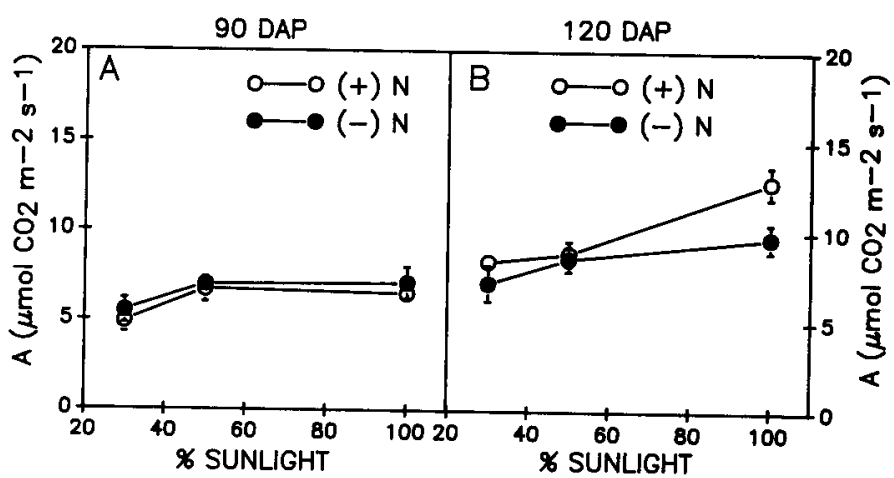

Fig. 4. Effect of percent sunlight and $\mathrm{N}$ on net $\mathrm{CO}_{2}$ assimilation of cocoyam (A) 90 and (B) 120 DAP. Each point represents the mean of six determinations. Vertical bars represent \pm SE. In some cases, SE bars were smaller than the symbols.

180 DAP (data not shown). Chlorophyll concentrations on a dry-weight basis ranged from 60 to $75 \mathrm{mg} \cdot \mathrm{g}^{-1}$ and were similar between $\mathrm{N}$ treatments when shade treatments were pooled 140 DAP. Chlorophyll concentrations were greater for $+\mathrm{N}$ than for - N plants only for the $30 \%$ - and $50 \%$-sunlight plants 180 DAP (Fig. 6A). Chlorophyll concentrations were higher for $30 \%$ than for $100 \%$-sunlight plants only for the $+\mathrm{N}$ plants 180 DAP (Fig. 6A). Chlorophyll contents on a lamina-area basis were higher for $+\mathrm{N}$ than for $-\mathrm{N}$ plants for all shade treatments. Mean chlorophyll $(\mathrm{a}+\mathrm{b})$ contents were 0.40 for $+\mathrm{N}$ plants, com- 


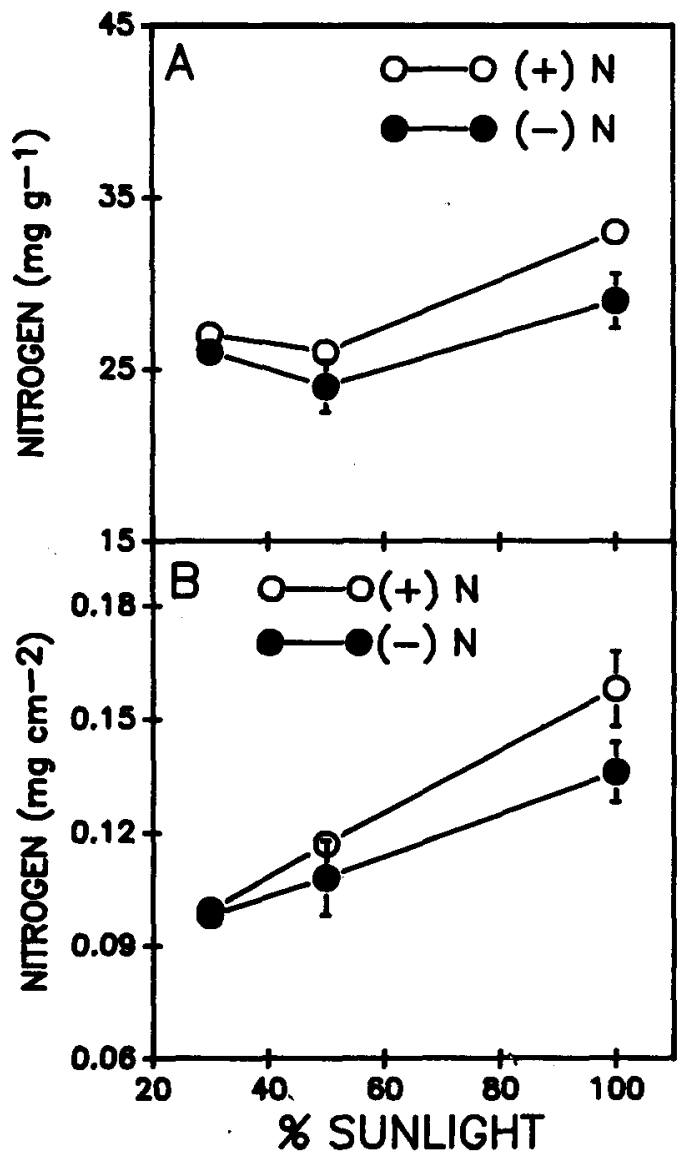

Fig. 5. Effect of percent sunlight and $\mathrm{N}$ on lamina $\mathrm{N}$ concentration of cocoyam on (A) dry-weight and (B) lamina-area basis. Each point represents the mean of 10 values 140 DAP. Vertical bars represent \pm SE. In most cases, SE bars were smaller than the symbols.

pared to $0.33 \mathrm{mg} \cdot \mathrm{cm}^{-2}$ for the $-\mathrm{N}$ plants when shade treatments were pooled 180 DAP. Chlorophyll contents on a laminaarea basis were not affected by shade for either $\mathrm{N}$ treatment 140 or 180 DAP (data not shown). Lamina chlorophyll content per plant was higher for $+\mathrm{N}$ than for $-\mathrm{N}$ plants for all shade treatments and increased with increased shade for both $\mathrm{N}$ treatments (Fig. 6B).

\section{Discussion}

Increased lamina area with increased $\mathrm{N}$ application rate has been documented for several plant species (Bouma, 1970; Evans and Seeman, 1984; Field and Mooney, 1986; Sage et al., 1987; Seeman et al., 1987; Thompson et al., 1988). For cocoyam, the effect of $\mathrm{N}$ on lamina area per plant was greater for plants exposed to $30 \%$ of natural sunlight than for those exposed to $50 \%$ or $100 \%$, which indicated that $30 \%$-sunlight plants allocated more $\mathrm{N}$ toward lamina area production than did the others. Similarly, shade plants (30\% and 50\% sunlight) exhibited greater foliage biomass and top : corm ratios at high $\mathrm{N}$ levels than $100 \%$-sunlight plants. The greater lamina area for $+\mathrm{N}$ plants may result in greater yields, since lamina expansion rates have been correlated with yields for several plant species (Potter and Jones, 1977), including cocoyam (unpublished data). Net gas exchange was similar for plants in both $\mathrm{N}$ treatments 90 DAP, which indicates that the growing media provided sufficient $\mathrm{N}$ for photosynthesis and growth. Since lamina area per plant for $+\mathrm{N}$ plants was $7.5 \%$ greater $75 \mathrm{DAP}$ and $9 \%$ greater $105 \mathrm{DAP}$

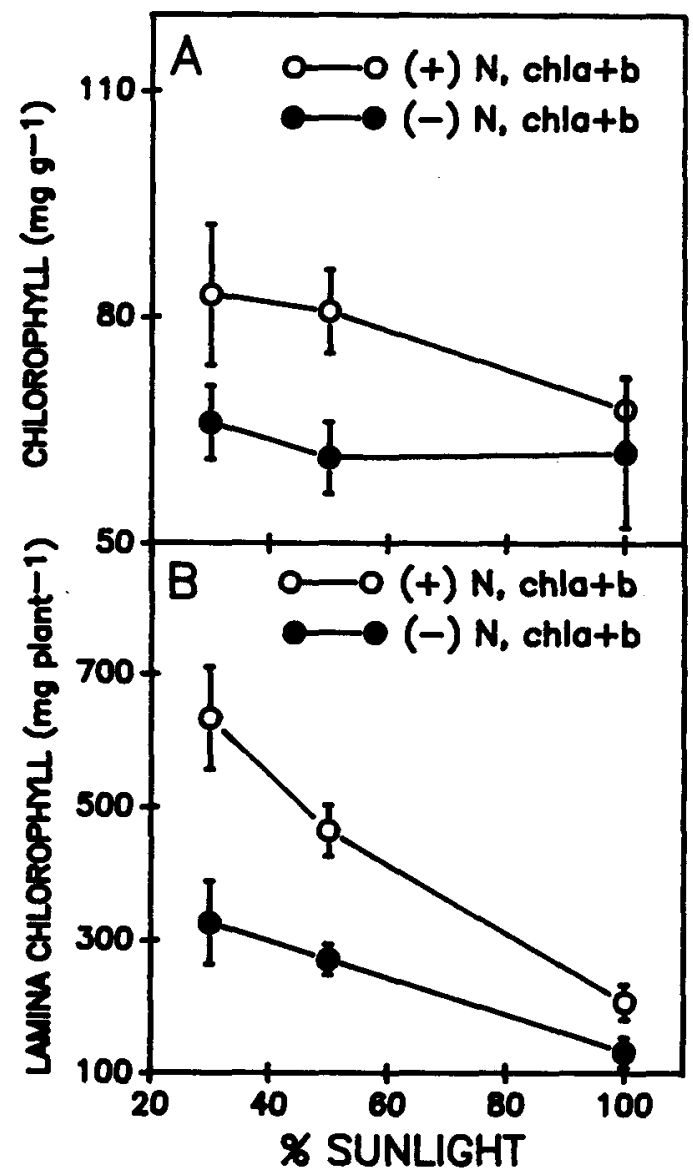

Fig. 6. Effect of percent sunlight and $\mathrm{N}$ on chlorophyll concentration of cocoyam on a (A) dry-weight and (B) per-plant basis 180 DAP. Each point represents the mean of five or six values. Vertical bars represent $\pm \mathrm{SE}$

than that of the $-\mathrm{N}$ plants, when shade treatments were pooled, it would be expected that lamina area was also greater for $+\mathrm{N}$ than for $-\mathrm{N}$ plants 90 DAP. Therefore, less lamina for the $-\mathrm{N}$ than for the $+\mathrm{N}$ plants 90 DAP indicated that the $-\mathrm{N}$ plants maintained increased $\mathrm{A}$ rates at the expense of lamina area. A, $\mathrm{g}_{\mathrm{s}}$, and WUE were higher for the $+\mathrm{N}$ than for the $-\mathrm{N}$ plants 120 DAP, especially for the $100 \%$-sunlight plants. Thus, by 120 DAP, the limited $\mathrm{N}$ pool in the growing medium had been depleted and $-\mathrm{N}$ plants lacked sufficient $\mathrm{N}$ for optimum gas exchange. The increase in lamina $\mathrm{N}$ concentration for $+\mathrm{N}$ and not for $-\mathrm{N}$ plants observed in the present study also resulted in increased $\mathrm{g}_{\mathrm{s}}$ (DeJong, 1982; Jurik et al., 1982; Longstreth and Nobel, 1980; Morgan, 1988) and increased WUE (Bolton and Brown, 1980) for several other plant species. Among shade treatments, A of the $100 \%$-sunlight plants was higher for the $+\mathrm{N}$ than for the $-\mathrm{N}$ plants. This observation was also reported for Lepechinia calycina (Field, 1983). Plants grown in full sunlight generally use more $\mathrm{N}$ than shade-grown plants (Joiner et al., 1977) due to the increased demand for $\mathrm{N}$ to sustain the higher growth observed in direct sunlight (Bjorkman, 1981; Givnish, 1988). In addition, increased $\mathrm{N}$ increases a plant's ability to acclimate to increased PPF (Ferrar and Osmond, 1986; Joiner et al., 1977; Osmond and Chow, 1988; Seeman et al., 1987). Therefore, $\mathrm{N}$ deficits maybe more detrimental for $100 \%$ sunlight than for shade-grown plants, as reported for Flindersia brayleyana (Thompson et al., 1988), Lepechinia (Field, 1983), and as shown by data from the present study (Fig. 4B). 
The effect of applied $\mathrm{N}$ on lamina chlorophyll concentration (dry-weight basis) was greater for the shade plants $30 \%$ and $50 \%$ sunlight) than for those growing in direct sunlight, indicating a greater emphasis by the shade plants to allocate $\mathrm{N}$ toward light absorption. Seeman et al. (1987) observed greater chlorophyll concentrations (dry-weight basis) with increased shade for Alocasia. In the present study, chlorophyll contents on an area basis were higher for $+\mathrm{N}$ than for $-\mathrm{N}$ plants, but were not affected by shade. Sims and Pearcy (1989) also found similar chlorophyll contents on an area basis among shade treatments for Alocasia and Colocasia. However, in our study, chlorophyll content determined on a whole-plant basis was higher' for shaded plants (30\% and 50\% sunlight) than for plants grown in full sunlight.

Interdictions between $\mathrm{N}$ and shade indicate that cocoyam response to $\mathrm{N}$ depends on incident PPF. A positive correlation may exist between $\mathrm{A}$ and lamina $\mathrm{N}$ concentration for cocoyam, as was shown with many other plants (Evans, 1989; Field and Mooney, 1986) and related aroids (Seeman et al., 1987; Sims and Pearcy, 1989). The interaction between $\mathrm{A}$ and lamina $\mathrm{N}$ concentration for cocoyam indicates a tendency toward maximizing A when grown in full sunlight, When grown in the shade, cocoyam allocated $\mathrm{N}$ toward light absorption in the form of greater foliage biomass. Cocoyam thus exhibited a degree of adaptive plasticity, with respect to $\mathrm{N}$ allocation within the lamina, in response to light intensity and nutrition during plant development. Despite greater $\mathrm{N}$ allocation toward light absorption, shade-grown cocoyam had greater corm biomass than $100 \%$ sunlight plants for both $\mathrm{N}$ and $\mathrm{N}$-free fertilized plants. The corm yield advantage for. shade plants is attributable to the greater crop growth rates observed for shade than for $100 \%$-sunlightgrown cocoyam (unpublished data). The greater foliage biomass for shaded cocoyam resulted in increased light interception and translocation of photosynthates to the roots (unpublished data). The thinner leaves observed for shaded cocoyam also may result in decreased maintenance and respiratory costs than for $100 \%$ sunlight-grown plants (Givnish, 1988; Thompson et al., 1988), as reported for Alocasia and Colocasia (Sims and Pearcy, 1989). The lower leaf temperatures commonly found in canopy understories also would contribute to decreased respiratory costs than for plants grown in direct sunlight. Thus, cocoyam has the potential to grow in moderate shade without sacrificing yields, especially in tropical agroecosystem polycultures where $\mathrm{N}$ deficits are common and where fertilizer costs are often prohibitive..

\section{Literature Cited}

Bjorkman, O. 1972. Photosynthetic adaptation to contrasting light climates. Carnegie Inst. Washington Yrbk. 71:82-85.

Bjorkman, O. 1981. Responses to different quantum flux densities, p. 57107. In: O.L. Lange, P.S. Nobel, C.B. Osmond, and H. Ziegler (eds.). Physiological plant ecology. I. Encyclopedia of plant physiology. vol 12A. Springer-Verlag, Berlin.

Bolton, J.K. and R.H. Brown. 1980. Photosynthesis of grass species differing in carbon dioxide fixation pathways. Plant Physiol 66:97-100.

Bouma, D. 1970. Effects of nitrogen nutrition on leaf expansion and photosynthesis of Trifolium subterraneum L. 1. Comparison between different levels of nitrogen supply. Ann. Bet. 34:1131-1142.

Chow, W. S., L. Qian, D.J. Goodchild, and J.M. Anderson. 1988. Photosynthetic acclimation of Alocasia macrorrhiza (L.) G. Don to growth irradiance: Structure, function and composition of chloroplasts. Austral. J. Plant Physiol. 15:107-122.

DeJong, T.M. 1982. Leaf nitrogen content and CO, assimilation capacity in peach. J. Amer. Soc. Hort. Sci. 107:955-959.
Evans, J.R. 1989. Photosynthesis and nitrogen relationship in leaves of $\mathrm{C}_{3}$ plants. Oecologia 78:9-19.

Evans, J.R. and J.R. Seeman. 1984. Differences between wheat genotypes in specific activity of ribulose- 1,5-bisphosphate carboxylase and the relationship to photosynthesis. Plant Physiol. 74:759-765.

Farineau, J., A. Suzuki, and J.F. Morot-Gaudry. 1988. Changes in the activation state of Rubisco in bean leaves in relation to recovery of photosynthetic activity after various treatments. Plant Sci. 55:191-198.

Ferrar, P.J. and C.B. Osmond. 1986. Nitrogen supply as a factor influencing photoinhibition and photosynthetic acclimation after transfer of shade-grown Solanum dulcamara to bright light. Planta 168:563-570.

Field, C. 1983. Allocating leaf nitrogen for the maximization of carbon gain: Leaf age as a control on the allocation program. Oecologia 56:341347.

Field, C. and H.A. Mooney. 1986. The photosynthesis-nitrogen relationship in wild plants, p. 25-56. IN: T.J. Givnish (cd.). On the economy of plant form and function. Cambridge univ., Cambridge, England.

Givnish, T.J. 1988. Adaptation to sun and shade: A whole-plant perspective. Austral. J. Plant Physiol. 15:63-92. --

Joiner, J. N., C.A. Conover, and R.T. Poole. 1977. Factors affecting acclimization of foliage plants. Proc. Trop. Reg. Amer. Soc. Hort. Sci. 21:41-43.

Jurik, T. W., J.F. Chabot, and B.F. Chabot. 1982. Effects of light and nutrients on leaf size, $\mathrm{CO}_{2}$ exchange, and anatomy in wild strawberry (Fragaria virginiana). Plant Physiol. 70:1044-1048.

Lawlor, D. W., M. Kontturi, and A.T. Young. 1989. Photosynthesis by flag leaves of wheat in relation to protein, RuBP carboxylase activity and nitrogen supply. J. Expt. Bet. 40:43-52.

Longstreth, D.J. and P.S. Nobel. 1980. Nutrient influences on leaf photosynthesis. Plant Physiol. 65:541-543.

Marini, R.P. and M.C. Marini. 1983. Seasonal changes in specific leaf weight, net photosynthesis, and chlorophyll content of peach leaves as affected by light penetration and canopy position. J. Amer. Soc. Hort. Sci. 108:600-605.

Morgan, J.A. 1988. Growth and canopy carbon dioxide exchange rate of spring wheat as affected by nitrogen status. Crop Sci. 28:95-100.

Osmond, C.B. and W.S. Chow. 1988. Ecology of photosynthesis in the sun and shade: Summary and prognostications. Austral. J. Plant Physiol. 15:1-11.

Potter, J.R. and J.W. Jones. 1977. Leaf area partitioning as an important factor in growth. Plant Physiol. 59:10-14.

Sage, R. F., R.W. Pearcy, and J.R. Seeman. 1987. The nitrogen usc efficiency of $\mathrm{C}_{3}$ and $\mathrm{C}_{4}$ plants. Plant Physiol. 85:355-359.

Schaffer, B. and G.O. Gaye. 1989. Gas exchange, chlorophyll and nitrogen content of mango leaves as influenced by light environment. HortScience 24:507-509.

Schaffer, B. and S.K. O'Hair. 1987. Net $\mathrm{CO}_{2}$ assimilation of taro and cocoyam as affected by shading and leaf age. Photosynthesis Res. 11:245251.

Seeman, J. R., T.D. Sharkey, J. Wang, and C.B. Osmond. 1987. Environmental effects on photosynthesis, nitrogen use efficiency, and metabolize pools in leaves of sun and shade plants. Plant Physiol. 84:796-802.

Sims, D.A. and R.W. Pearcy. 1989. Photosynthetic characteristics of a tropical forest understory herb, Alocasia macrorrhiza, and a related crop species, Colocasia esculenta grown in contrasting light environments. Oecologia 79:53-59.

Sinclair, T.R. and T. Horie. 1989. Leaf nitrogen, photosynthesis, and crop radiation use efficiency: A review. Crop Sci. 29:90-98.

Suzuki, S., H. Nakamoto, M.S.B. Ku, and G.E. Edwards. 1987. Influence of leaf age on photosynthesis, enzyme activity, and metabolize levels in wheat. Plant Physiol. 84:1244-1248.

Terashima, I. and J.R. Evans. 1988. Effects of light and nitrogen nutrition on the organization of the photosynthetic apparatus in spinach. Plant Cell Physiol. 29:143-155.

Thompson, W.A., G.C. Stocker, and P.E. Kridemann. 1988. Growth and photosynthetic response to light and nutrients of Flindersia brayleyana F. Muell., a rainforest tree with broad tolerance to sun and shade. Austral. J. Plant Physiol. 15:299-316. 